\title{
Social determinants of mammography screening among women aged 50 to 59, Peru 2015
}

\author{
Authors \\ Sergio Chang-Cabanillas ${ }^{1}$ \\ $(0000-0002-5698-8447)$ \\ Joshua Peñafiel-Sam ${ }^{1}$ \\ $(0000-0003-4667-7351)$ \\ Samuel Alarcón-Guevara ${ }^{1} \quad$ (0000-0003-1276-8431) \\ Reneé Pereyra-Elías ${ }^{1,2} \quad$ (0000-0001-6398-4287) \\ 1) School of Medicine, Universidad Peruana de Ciencias Aplicadas, Lima, Perú. \\ 2) National Perinatal Epidemiology Unit, Nuffield Department of Population Health, \\ University of Oxford, Oxford, United Kingdom.
}

\begin{abstract}
Breast cancer (BC) screening could reduce its mortality; however, its access is influenced by societal forces. Our objective is to identify the social determinants associated with mammography screening (MS) in women aged 50 to 59 in Peru. In this cross-sectional analysis of the Peruvian Demographic Health Survey, 2015, MS within the past two years was evaluated through selfreport. Prevalence for MS was $21.9 \%$ [95\% CI: 18.9 to 25.1]. The average age was 54 years (s.d.:2.5). The higher the socioeconomic status, the higher the prevalence of screening $(3.2 \% \mathrm{vs}$ $41.4 \%$ in extreme quintiles, $\mathrm{p}<.001)$. In the adjusted models, higher socioeconomic status (PR: 5.81, 95\% CI: 2.28 to 14.79 ), higher education level (PR: $2.03,95 \%$ CI: 1.30 a 3,15) and having health insurance from the Ministry of Health (PR: 2.21, 95\% CI: 1.28 to 3.82) and EsSalud (PR: 4.37, 95\% CI: 2.67 to 7.15), were positively associated with MS. Social inequalities in screening access exist and might translate into inequalities in cancer morbidity and mortality. The Peruvian government urgently needs to improve screening rates in these vulnerable populations.
\end{abstract}

Keywords: Mammography; screening; breast cancer; social determinants of health; health inequalities; health disparities; Peru 


\section{Background}

The circumstances in which we live, directly and indirectly, influence the health of the population. These circumstances are known as the social determinants of health, which include structural factors (such as the political and economic context, health policies, development programs, among others) and proximal factors (such as the individual socioeconomic status, education, ethnicity, etc) (WHO, 2007). Health and disease are differentially distributed according to these determinants, which is considered unjust, unfair and unacceptable (WHO, 2007; Artica, 2018; Marmot, 2005).

Among several disadvantages, people in a lower socioeconomic position have less access to health services, a greater burden of disease, poorer quality of life and earlier mortality (Marmot, 2005). Social circumstances can also prevent access to healthcare and measures of primary and secondary prevention. Recently, the Pan American Health Organization released the report of the Commission on Equity and Health Inequalities in the Americas. They showed that countries in the region, such as Peru, still face important socioeconomic inequalities in attending basic health needs, such as access to modern contraception (PAHO, 2019). Previous research has also found considerable socioeconomic gaps in access to cervical cancer screening (Gutiérrez et al, 2010; Paz Soldan et al, 2008). Evidence regarding inequalities in other cancer screening strategies is scarce.

Breast cancer (BC) is the third most frequent cancer in Peru (after cervical and stomach cancer), with an annual incidence of 28 cases per 100000 inhabitants, which has apparently been increasing in the past decade (Instituto Nacional de Enfermedades Neoplásicas [INEN], 2016; Ghoncheh et al., 2016; Dirección General de Epidemiología [DGE], 2013). Nevertheless, this cancer is usually diagnosed during late stages and early detection through mammography screening (MS) could reduce its mortality (Myers et al., 2015). Prevention guidelines from Peruvian Social Security (EsSalud) recommend a biennial mammogram in asymptomatic women aged 50 to 74 years (Baffigo et al., 2015). The National Plan for the Prevention and Control of Breast Cancer in Peru (2017 - 2021), developed by the Ministry of Health (MoH) recommends biennal MS from 50 to 69 years of age (Ministerio de Salud [MINSA], 2017). These recommendations are similar to those of the World Health Organization (WHO) (biennially in women aged 50 to 69) and those of the Canadian Task Force On Preventive Health Care and the United States Preventive Services Task Force (biennially in women aged 50 to 74) (WHO, 2014; Tonelli et al., 2011; Nelson et al., 2016). However, in Peru, there is evidence of poor mammography coverage, with only one mammography machine for an estimated 30 to 75 thousand women (Ramos et al., 2013). Furthermore, it is likely that access to MS is not similar across all members of society. We have not found Peruvian studies evaluating if there are social inequalities in MS. Therefore, our aim is to evaluate the social determinants associated with MS in the Peruvian female population aged 50 to 59 years.

\section{Methods}

\section{Study design and population}

We carried out a cross-sectional analysis of the Peruvian Demographic Health Survey (DHS), 2015. The National Institute of Statistics and Informatics (Instituto Nacional de Estadística e Informática, INEI) conduct the survey annually and select a nationally-representative sample, through a multistage stratified sampling method (INEI, 2016).

In our secondary data analysis, we included women aged 50 to 59 , because that age group benefits from the highest reductions in mortality due to MS and is the target of most prevention guidelines (WHO, 2014; Tonelli et al., 2011; Nelson et al., 2016). We excluded women aged 40 to 49 years because of its controversial recommendation (not consensus), since it is associated with 
overdiagnosis and unnecessary treatment (Posso et al., 2015). No women aged 60 or older were asked about MS in the DHS (INEI, 2016).

Dependent variable

We used the self-report of MS within the past two years. It was evaluated through the question: 'Have you ever had a mammography test carried out by a doctor or other health professional?', with three alternatives: 'yes', 'no', and 'do not know'. If they answered 'yes', then they were required to answer: 'How long ago was the last mammography screening?', with three alternatives: 'less than two years ago', 'two or more years ago' and 'Cannot remember'. For the purposes of our study, we generated a dichotomous variable 'Mammography screening within the past two years' (yes vs no) (INEI, 2016).

\section{Independent variables}

The independent variables of interest were the following social determinants of health: i) geographical region (Lima Metropolitan Region, rest of the coast, highlands and jungle), ii) residence area (urban or rural), iii) socioeconomic status (wealth index according to the INEI methodology, divided into quintiles) and iv) education (less than high school, complete high school and more than high school). We additionally evaluated health insurance, according to type of coverage: No insurance, Health Insurance of the Ministry of Health (Seguro Integral de Salud, SIS), Health Insurance of the Ministry of Labor (EsSalud), Health Insurance of the Armed and Police Forces and private insurance. We collapsed private and Armed and Police Forces insurance and multiple insurances together because of paucity of observations.

In addition, age (years) and marital status (married/cohabiting, yes vs no) were evaluated as covariates. Being married is associated with a greater performance of mammography and even a group of female population in our country have access to health insurance due to their marital status (Martín-López et al., 2013; Schneider et al., 2014; Cabeza et al., 2007; Hanske et al., 2016).

\section{Data analysis}

We performed the data analysis using the statistical package Stata 13.0 (StataCorp, College Station, TX, USA). All analyses considered the multi-stage design of ENDES 2015 (svy module). We used the sample weights and other parameters that were provided by the DHS. The analyses were carried out considering a significance level of $5 \%$.

In the descriptive analysis, we calculated the prevalence of self-reported MS within the past two years and its $95 \%$ confidence interval $(95 \% \mathrm{CI})$. In the bivariate analysis, we compared the prevalence of MS across the different strata of the social determinants of health, using chi-square test. We used generalized linear models of the Poisson family and log link function to calculate crude and adjusted prevalence ratios (PR and aPR) with their respective 95\% CI.

In the multivariable models, we analyzed each exposure of interest (rurality, natural region, socioeconomic status, educational level, health insurance) (Nelson, 2016; WHO, 2007; Artica, 2018), adjusted for: i) Model 1: age and marital status; ii) Model 2: Age, marital status and the other exposure variables. We verified the non-existence of multicollinearity between the independent variables.

\section{Ethical aspects}

The research protocol was exempted from review by the Research Ethics Committee of the Faculty of Health Sciences of Universidad Peruana de Ciencias Aplicadas (UPC). The analyzed dataset does not contain personal information that allows the participants to be identified and is openly available to the public domain. 


\section{Results}

From a total of 18,250 women surveyed in the DHS, 13,980 were excluded because they were younger than 50 years of age. Then, 2,462 women were not included because they did not have data for the outcome of interest, which yielded a final sample of 1,808 women (Figure 1).

Approximately, $21.9 \%$ of women reported having undergone MS within the past two years [ $95 \%$ CI: $18.9 \%$ to $25.1 \%$ ]. The average age of the population was 54.1 years (s.d., 2.5). Most women lived in an urban area (75.4\%) and had an educational level of primary or less $(43.4 \%)$. The health insurance coverage was $74.8 \%$ and most of them had Ministry of Health insurance. The characteristics of the sample are detailed in Table 1.

When comparing the prevalence of MS according to the evaluated social stratifiers, we found gradients for the measures of socioeconomic position, as well as differences according to rurality and natural region of residence. The prevalence was higher in women of higher socioeconomic status $(3.2 \%$ in the poorest quintile vs $41.4 \%$ in the richest quintile, $p<0.001)$ and in women with the highest educational level $(10.2 \%$ in those who did not complete secondary education vs $44 \%$ in those who achieved a higher education, $\mathrm{p}<0.001)$. Compared to women living in urban areas, those who lived in rural areas were less likely to report the screening $(5.1 \%$ vs. $27.4 \%, \mathrm{p}<0.001)$. Approximately, 34\% of women living in Lima had a mammography, while in other regions of the country, this proportion was less than $20 \%$. The prevalence of the outcome was also higher among women who had health insurance; likewise, there were differences between the different types of insurance. The details of the bivariate analysis can be found in Table 2 and Figure 2.

In the multivariable analysis, we found that women from the highest socioeconomic status were almost six times more likely to report the screening than women at the lowest socioeconomic status, independently of all the other variables [aPR: 5.81; 95\% CI: 2.28 to 14.79 ]. Likewise, compared to those women with no complete high school education, those with higher education were twice as likely to report MS [aPR: 2.03 ; $95 \%$ CI: 1.30 to 3.15]. On the other hand, women who had some type of health insurance were at least twice as likely to report the screening than uninsured participants [SIS-Ministry of Health: aPR: 2.21 ; 95\% CI:1.28 to 3.82]; [EsSalud: PR: 4.37; 95\% CI: 2.67 to 7.15]; [Other: PR: 4.96 95\% CI: 2.81 to 8.75]. The results from the multivariable models are found in Table 3.

\section{Discussion}

Our results show that approximately $20 \%$ of Peruvian women reported having undergone mammography in the past two years; however, this proportion was dramatically different according to socioeconomic status, educational level and health insurance. This shows important avoidable gaps between different strata of the population. The most intuitive explanation to these findings would be to think that these differences are due to inequalities in health provision by the Peruvian health services. And this is a likely scenario given that the country has a highly fragmented health system and that approximately a quarter of the population was uninsured for 2015 (INEI, 2016). However, social inequalities in health are evident in most countries, including those with universal health coverage (Bartley, 2017; CSDH, 2008; Marmot, 2010). Developed and developing countries, with and without universal coverage, have failed to reduce in social inequalities in health (CSDH, 2008; Johar et al., 2018; Li \& Shao, 2015; Marmot, 2010; Vieira et al., 2017;). Therefore, health services themselves do not seem to explain all the variation in access to healthcare. The World Health Organization states that socioeconomic disadvantage limits access to healthcare through different barriers, not only including those factors that are intrinsically economic, but also work-related restrictions, cultural factors or co-existent illnesses 
that can considerably limit access to healthcare (CSDH, 2008; WHO, 2007; Wilkinson \& Marmot, 2003).

The percentage of MS found in this study is slightly lower to that of neighboring countries like Chile (22\%), Argentina (27\%) or Brazil (34\%) (Reyes-Ortiz et al., 2006) and way below that of developed countries, such as US (66\%), UK (74\%), Australia (56\%), Italy (59\%) and France (44\%) (Dowling et al., 2010). While the overall proportion of MS in Peru was around 20\%, it was only $3 \%$ among women in the lowest wealth quintile. Also, a lower wealth index was one of the strongest determinants that prevented access to MS, even after controlling for potential confounders. Similar findings have been reported in developed countries like Spain, Italy and France, where women with higher incomes were up to $20 \%$ to $30 \%$ more likely to report the screening. (Martín-López et al., 2013; Damiani et al., 2012; Duport \& Ancelle-Park, 2006). In Brazil, Schneider (2014) observed that women in the upper wealth quartile were twice more likely to get a mammogram. As well as Brazil, previous research in samples from Argentina (PAHO, 2010) and Colombia (Castillo-Ávila et al., 2014) have yielded same results. It is important to notice that the strength of the association found in our study is much higher than in those reports. This greater inequality could be due to: i) Different measures of the variable income/wealth, ii) Different categorizations of the variable (quintiles in our study are more sensitive to greater differences than quartiles or binary exposures, like the study by Martín-López (Martín-López et al., 2013), or iii) That a lower socioeconomic status, in Peru, poses greater disadvantage in terms of access to health than in other countries. It is especially remarkable that these differences persist, even after accounting for the level of education, rurality and health insurance, which also influence MS.

We found that MS prevalence was significantly lower in rural areas; however, these differences vanished after controlling for other variables. This is because Peruvian rural populations are more likely to be poor, less educated and uninsured, and the multivariable regression accounted for their confounding effect (Posso et al., 2015). A Korean study found that living in a rural area was positively associated to have ever had a mammogram in women aged 40 to 74 years (Park et al., 2011). However, researchers from Argentina (PAHO, 2010), Brazil (Moreira et al., 2018), Mexico (Agudelo-Botero et al., 2013) and the US (Chandak et al., 2018) have reported a higher mammography uptake among residents of urban areas. Similar patterns have been found in eastern countries (Aminisani et al., 2016; Kulkarni et al., 2018). Better public health policies should be encouraged to achieve equal goals in rural health coverage. The differences we initially found between Lima and the other regions could be similarly explained, given that the Highlands and the Jungle have also a higher proportion of rural, less educated and less wealthy citizens.

Women with higher education were more likely to have had a mammography in the previous two years. This was also found in a systematic review of studies from North America and Europe (Damiani et al., 2015), where a high educational level was positively associated with MS. Research conducted in South American countries has yielded similar results (Schneider et al., 2014; PAHO, 2010; Castillo-Ávila et al., 2014). In contrast, Documèt (2015) and Kwok (2014) did not find significant differences between education and mammography. Their findings could be explained by the existence of lower inequalities, due to better social policies in their respective countries. Peru still has difficulties to guarantee education in the poorest and most remote areas, and improving this indicator could potentially reduce inequalities in access to screening and other health services (Cárdenas et al., 2017; De la Torre-Ugarte-Guanilo \& Oyola-García, 2014; MINSA, 2017).

Health insurance should be universal according to the WHO, but poor coverage of Peruvian population persists, which significantly limits their access to health care. Health coverage is associated with a higher rate of mammograms compared to those that do not have insurance, as found by Aminisani (2016), Documèt (2015), Calo (2016), Henry (2014) and in our study. There were also differences between types of insurance. Those covered by EsSalud and Private/Police 
and Armed forces were more than four times more likely to report MS. In Latin America, studies shows that women without health insurance are less likely to access MS than those who have insurance (Agudelo-Botero et al., 2013; Castillo-Ávila et al., 2014; Charry et al., 2008; Moreira et al., 2018; PAHO, 2010). Along with the lack of health insurance, the main barriers to accessing health care are financial problems, and poor health literacy (Mezones-Holguin et al., 2019; Soto, 2019), and these gaps are much wider if we look for vulnerable populations, whether in Peru (DGE, 2012) or other countries (Olorunsaiye et al., 2020; Olukotun et al., 2019; Steiness et al., 2018). Health policies must also focus on these barriers when planning to reduce health inequalities. In the case of Peru, there have been certain reforms in national health policies (Mezones-Holguin et al., 2019); but these had only led to modest improvements in cancer mortality and recent survival trends (Poma, 2017; Tamayo et al., 2018; Zafra-Tanaka et al., 2020). This could be explained by late diagnosis and treatment due to the lack of timely screening (Marmot, 2017).

We could argue that guaranteeing access to a universal health insurance might not be enough to reduce inequalities. There are deficiencies in our national health services (most importantly in important segments of the public sector, such as the Ministry of Health). These include a low supply of general and specialized human resources for health, (Zevallos et al., 2011) as well as poor infrastructure to cover health care needs (Soto, 2019). It is also important to note that Peru does not have enough equipment in all regions and there is a deficit of mammographs, especially in the less wealthy provinces. According to the latest data (MINSA, 2017), Peru has 202 establishments with mammographs, and approximately of them belong to the private sector. From the 52 mammographs of the Ministry of Health (biggest provider of the public sector), only 37 would be operational by that date and most of them would be in the capital, Lima. On the other hand, Argentina (INC, 2018), with a population approximately $40 \%$ higher than the Peruvian population, had 377 mammograms were registered, only in the public sector.

The study has limitations to consider. First, we cannot infer that reporting MS in the past two years means the recommended continuous biennial screening. Second, self-report might be subject to measurement bias, as they may not remember accurately. However, breaking the assessment of the variable into two questions (one for the occurrence and one for the timing) might reduce this problem. Third, Peruvian DHS did not evaluate a potential confounder, which is parity. Nulliparous women are more likely to develop BC and, therefore, could be targeted with preventive measures, such as screening. Also, nulliparity is more common among urban, richer and more educated women. This might probably have reduced the strength of the associations we have found. However, we did control for a proxy of this variable (marital status).

\section{Conclusion}

In conclusion, one in every five Peruvian women aged 50 to 59 years reported MS within the past two years. Women from lower socioeconomic status, lower education and uninsured women were less likely to report having had screening. Inequalities in access to screening services might potentially translate into inequalities in cancer morbidity and mortality. Thus, we strongly recommend that government authorities pay attention to our results for the execution of future health policies to reduce these inequalities. Interventions must target these vulnerable populations. 


\section{References}

Agudelo-Botero, M. (2013). [Sociodemographic determinants of access to breast cancer screening in Mexico: a review of national surveys]. Salud Colect, 9(1), 79-90. doi:10.1590/S1851-82652013000100007

Aminisani, N., Fattahpour, R., Dastgiri, S., Asghari-Jafarabadi, M. \& Allahverdipour, H. (2016). Determinants of breast cancer screening uptake in Kurdish women of Iran. Health Promot Perspect, 6(1), 42-6. doi:10.15171/hpp.2016.07

Artica, M. (2018). Los Objetivos de Desarrollo Sostenible y el Parlamento Peruano. Lima, Peru: Congreso de la República del Perú. Retrieved from: http://www.congreso.gob.pe/Docs/OCI/Interface/files/reporte_parlamento_agenda_2030.pdf

Baffigo, V., La Rosa, M. A., Sánchez, M., \& Lazo, R. (2016). Detección temprana del cáncer de mama en EsSalud. Lima, Peru: Ministerio del Trabajo. Retrieved from:http://www.essalud.gob.pe/ietsi/pdfs/guias/DIREC DETECCION TEMP CANCER MAMA.pdf

Bartley, M. (2017). Health inequality: An introduction to concepts, theories and methods. 2nd ed. Cambridge, United Kingdom: Polity Press.

Cabeza, E., Esteva, M., Pujol, A., Thomas, V., \& Sanchez-Contador, C. (2007). Social disparities in breast and cervical cancer preventive practices. Eur J Cancer Prev, 16(4), 372-379. doi:10.1097/01.cej.0000236243.55866.b0

Calo, W. A., Vernon, S.W., Lairson, D. R., \& Linder, S. H. (2016). Area-level Socioeconomic Inequalities in the Use of Mammography Screening: A Multilevel Analysis of the Health of Houston Survey. Womens Health Issues, 26(2), 201-7. doi:10.1016/j.whi.2015.11.002

Cárdenas, E., Juárez, C., Moscoso, R. \& Vivas, J. (2017). Determinantes sociales en salud. Lima, Peru: Universidad ESAN. from:https://www.esan.edu.pe/publicaciones/2017/09/29/DeterminantesSocialessaludCompl eto.pdf

Castillo-Ávila, I. Y., Bello-Triana, L. F., Castillo-Martelo, L., Moscote-Villadiego, G., OrozcoPayares, W. P., ... Visbal-Barón, M. P. (2014). Factors Associated with Use of Mammography in Women over 50 years. Cartagena. Rev Cienc Salud, 12(2), 183-193. doi:10.12804/revsalud12.2.2014.04

Chandak, A., Nayar, P. \& Lin, G. (2018). Rural-Urban Disparities in Access to Breast Cancer Screening: A Spatial Clustering Analysis. $J$ Rural Health, 35(2), 229-235. doi:10.1111/jrh. 12308

Charry, L. C., Carrasquilla, G., \& Roca, S. (2008). Equidad en la Detección del Cáncer de Seno en Colombia. Rev Salud Publica (Bogota), 10(4), 571-82. doi:10.1590/S003636342009000800015

Commission of the Pan American Health Organization on Equity and Health Inequalities in the Americas (2019). Just Societies: Health Equity and Dignified Lives. Report of the Commission of the Pan American Health Organization on Equity and Health Inequalities in the Americas. Washington, D.C.: PAHO. Retrieved from:http://iris.paho.org/xmlui/handle/123456789/51571

Commission on Social Determinants of Health (2008). CSDH final report: closing the gap in a generation: health equity through action on the social determinants of health. Geneva, Switzerland: WHO.

from:https://www.who.int/social determinants/final report/csdh finalreport 2008.pdf

Damiani, G., Federico, B., Basso, D., Ronconi, A., Bianchi, C. B., ... Ricciardi, W. (2012). Socioeconomic disparities in the uptake of breast and cervical cancer screening in Italy: a cross sectional study. BMC Public Health, 12,99. doi:10.1186/1471-2458-12-99

Damiani, G., Basso, D., Acampora, A., Bianchi, C. B., Silvestrini, G., Frisicale, E. M., ... Ricciardi, W. (2015). The impact of level of education on adherence to breast and cervical cancer screening: Evidence from a systematic review and meta-analysis. Prev Med, 81, 2819. doi:10.1016/j.ypmed.2015.09.011 
De la Torre-Ugarte-Guanilo, M. \& Oyola-García, A. (2014). Los determinantes sociales de la salud: una propuesta de variables y marcadores/indicadores para su medición. Rev Peru Epidemiol, 18(1), 1-6. Retrieved from:https://www.redalyc.org/pdf/2031/203132677002.pdf

Dirección General de Epidemiología (DGE) (2012). Análisis de Situación del Perú, 2012. Lima, Peru: DGE. Retrieved from:http://www.dge.gob.pe/portal/docs/intsan/asis2012.pdf

Dirección General de Epidemiología (DGE) (2013). Análisis de Situación del Cáncer en el Perú, 2013. Lima, Peru: DGE. Retrieved from:http://www.dge.gob.pe/portal/docs/asis_cancer.pdf

Documèt, P., Bear, T. M., Flatt, J. D., Macia, L., Trauth, J., \& Ricci, E. M. (2015). The association of social support and education with breast and cervical cancer screening. Health Educ Behav, 42(1), 55-64. doi:10.1177/1090198114557124

Dowling, E. C., Klabunde, C., Patnick, J., Ballard-Barbash, R. \& International Cancer Screening Network (ICSN) (2010). Breast and cervical cancer screening programme implementation in 16 countries. J Med Screen, 17(3),139-46. doi:10.1258/jms.2010.010033

Duport, N. \& Ancelle-Park, R. (2006). Do socio-demographic factors influence mammography use of French women? Analysis of a French cross-sectional survey. Eur J Cancer Prev, 15, 219-24. doi:10.1097/01.cej.0000198902.78420

Ghoncheh, M., Pournamdar, Z., \& Salehiniya, H. (2016). Incidence and Mortality and Epidemiology of Breast Cancer in the World. Asian Pac J Cancer Prev, 17(S3), 43-6. doi:10.7314/APJCP.2016.17.S3.43

Gutiérrez, C., Romaní, F., Ramos, J., Alarcón, E. \& Wong, P. (2010) Factores asociados con el conocimiento y tamizaje para cáncer de cuello uterino (examen de Papanicolaou) en mujeres peruanas en edad fértil. Análisis del periodo 1996-2008. Rev Peru Epidemiol, 14(1), 39-49. Retrieved from:https://dialnet.unirioja.es/servlet/articulo? codigo $=3989482$

Hanske, J., Meyer, C. P., Sammon, J. D., Choueiri, T. K., Menon, M., Lipsitz, S. R., ... QuocDien, T. (2016). The influence of marital status on the use of breast, cervical, and colorectal cancer screening. Prev Med, 89, 140-5. doi:10.1016/j.ypmed.2016.05.017

Henry, K. A., McDonald, K., Sherman, R., Kinney, A. Y., \& Stroup, A. M. (2014). Association between individual and geographic factors and nonadherence to mammography screening guidelines. J Womens Health (Larchmt), 23(8), 664-74. doi:10.1089/jwh.2013.4668

Instituto Nacional de Enfermedades Neoplásicas (INEN) (2016). Casos nuevos de cáncer registrados en INEN, Período 2000 - 2016. Lima ， Peru: INEN. Retrieved from:https://portal.inen.sld.pe/indicadores-anuales-de-gestion-produccion-hospitalaria/

Instituto Nacional de Estadística e Informática (INEI) (2016). Encuesta Demográfica y de Salud Familiar ENDES Continua 2015-2017. Lima, Peru: INEI. Retrieved from:www.minsa.gob.pe/portalweb/02estadistica/encuestas_INEI/

Instituto Nacional del Cáncer (INC) (2018). Resultados del Censo Nacional de Mamógrafos 2018. Buenos Aires, Argentina: INC. Retrieved from:http://www.msal.gob.ar/images/stories/bes/graficos/0000001310cnt-20180913-censonacional-mamografos-2018.pdf

Johar, M., Soewondo, P., Pujisubekti, R., Kunthara, H. \& Adji, A. (2018). Inequality in Access to Health Care, Health Insurance and the Role of Supply Factors. Soc Sci Med, 213, 134-145. doi:10.1016/j.socscimed.2018.07.044

Kulkarni, S. V., Mishra, G. A. \& Dusane, R. R. (2018). Determinants of Compliance to Breast Cancer Screening and Referral in Low Socio-Economic Regions of Urban India. Int J Prev Med, 10, 84. doi:10.4103/ijpvm.IJPVM_335_17

Kwok, C., \& Fong, D. Y. (2014). Breast cancer screening practices among Hong Kong Chinese women. Cancer Nursing, 37(1), 59-65. doi:10.1097/NCC.0b013e31827f0a9d

Li, J. \& Shao Z. (2015). Mammography screening in less developed countries. Springerplus, 4, 615. doi:10.1186/s40064-015-1394-8

Marmot, M. (2005). Social determinants of health inequalities. Lancet, 365(9464), 1099-104. doi:10.1016/S0140-6736(05)71146-6

Marmot, M. (2010). Fair Society, Healthy Lives: The Marmot Review. London: Institute of Health Equity. London, United Kingdom. Retrieved 
from:http://www.instituteofhealthequity.org/resources-reports/fair-society-healthy-lives-themarmot-review/fair-society-healthy-lives-full-report-pdf.pdf

Marmot, M. (2017). Social justice, epidemiology and health inequalities. Eur J Epidemiol, 32, 537-546. doi:10.1007/s10654- 017-0286-3

Martín-López, R., Jiménez-García, R., Lopez-de-Andres, A., Hernández-Barrera, V., JiménezTrujillo, I., Gil-de-Miguel, A., \& Carrasco-Garrido, P. (2013). national survey. Public Health, 127(9), 822-7. doi:10.1016/j.puhe.2013.03.006

Mezones-Holguín, E., Amaya, E., Bellido-Boza, L., Mougenot, B., Murillo, J. P. Villegas-Ortega, J. \& Del Carmen, J. C. (2019). Cobertura de aseguramiento en salud: el caso peruano desde la Ley de Aseguramiento Universal. Rev Peru Med Exp Salud Publica, 36(2), 196-206. doi:10.17843/rpmesp.2019.362.3998

Ministerio de Salud (MINSA) (2017). Documento técnico: Plan Nacional para la prevención y control del cáncer de mama en el Perú 2017 - 2021. Lima, Peru: MINSA. Retrieved from:http://bvs.minsa.gob.pe/local/MINSA/4234.pdf

Moreira, C. B., Fernandes, A. F. C., Castro, R. C. M. B., Oliveira, R. D. P. \& Pinheiro, A. K. B. (2018). Social determinants of health related to adhesion to mammography screening. Rev Bras Enferm, 71(1), 97-103. doi:10.1590/0034-7167-2016-0623

Myers, E. R., Moorman, P., Gierisch, J. M., Havrilesky, L. J., Grimm, L. J., Ghate, S., ... Sanders, G. D. (2015). Benefits and Harms of Breast Cancer Screening: A Systematic Review. JAMA, 314(15), 1615-34. doi:10.1001/jama.2015.13183

Nelson, H. D., Fu, R., Cantor, A., Pappas, M., Daeges, M., \& Humphrey, L. (2016). Effectiveness of Breast Cancer Screening: Systematic Review and Meta-analysis to Update the 2009 U.S. Preventive Services Task Force Recommendation. Ann Intern Med, 164(4), 244-55. doi:10.7326/M15-0969

Nuche-Berenguer, B. \& Sakellariou, D. (2019). Socioeconomic determinants of cancer screening utilisation in Latin America: A systematic review. PLoS One, 14(11), e0225667. doi:10.1371/journal.pone.0225667

Olorunsaiye, C. Z., Huber, L. B., Laditka, S. B., Kulkarni, S. \& Boyd, A. S. (2020). Factors associated with health facility delivery in West and Central Africa: A multilevel analysis of seven countries. Health Care Women Int, 41(1), 3-21. doi:10.1080/07399332.2019.1678161

Olukotun, O., Mkandawire-Valhmu, L. \& Kako, P. (2019). Navigating complex realities: Barriers to health care access for undocumented African immigrant women in the United States. Health Care Women Int. doi:10.1080/07399332.2019.1640703

Pan American Health Organization (PAHO). (2010). Cáncer de mama en Argentina: organización, cobertura y calidad de las acciones de prevención y control: informe final julio 2010 diagnóstico de situación del Programa Nacional y Programas Provinciales. Buenos Aires: PAHO. Retrieved from:http://www.msal.gob.ar/images/stories/bes/graficos/0000000006cnt01-cancer_de_mama.pdf

Park, M. J., Park, E. C., Choi, K. S., Jun, J. K., \& Lee, H. Y. (2011). Sociodemographic gradients in breast and cervical cancer screening in Korea: the Korean National Cancer Screening Survey (KNCSS) 2005-2009. BMC Cancer, 11, 257. doi:10.1186/1471-2407-11-257

Paz Soldan, V.A., Lee, F.H., Carcamo, C., Holmes, K.K., Garnett, G.P. \& Garcia, P. (2008). Who is getting Pap smears in urban Peru? Int J Epidemiol, 37(4), 862-9. doi:10.1093/ije/dyn118 7

Poma, P. A. (2017). Mujeres afectadas por cáncer de mama-Recomendaciones para el seguimiento. Rev Peru Ginecol Obstet, 63(1), 35-51. doi:10.31403/rpgo.v63i1962

Posso, M., Puig, T., \& Bonfill, X. (2015). Balance entre riesgos y beneficios del tamizaje mamográfico de cáncer de mama ¿apoyaría su recomendación en mujeres peruanas?. Rev Peru Med Exp Salud Publica, 32(1), 117-28. doi:10.17843/rpmesp.2015.321.1584

Ramos, W. C., Venegas, D. R., Medina, J. L., Guerrero, P. C., \& Cruz, A. (2013). Análisis de la situación del cáncer en el Perú, 2013. Lima, Peru: Dirección General de Epidemiología. Retrieved from:http://www.dge.gob.pe/portal/docs/asis_cancer.pdf

Reyes-Ortiz, C. A., Freeman, J. L., Peláez, M., Markides, K. S. \& Goodwin, J. S. (2006). Mammography use among older women of seven Latin American and Caribbean cities. Prev Med, 42(5), 375-80. doi:10.1016/j.ypmed.2006.02.005 
Schneider, I. J., Giehl, M. W., Boing, A. F., \& d'Orsi, E. (2014). [Mammogram screening for breast cancer and associated factors in the South of Brazil: a based-population survey]. Cad Saude Publica, 30(9), 1987-97. doi:10.1590/0102-311X00162313

Soto, A. (2019). Barreras para una atención eficaz en los hospitales de referencia del Ministerio de Salud del Perú: atendiendo pacientes en el siglo XXI con recursos del siglo XX. Rev Peru Med Exp Salud Publica, 36(2), 304-11. doi:10.17843/rpmesp.2019.362.4425

Steiness, H. S., Villegas-Gold, M., Parveen, H., Ferdousy, T. \& Ginsburg, O. (2018). Barriers to care for women with breast cancer symptoms in rural Bangladesh. Health Care Women Int, 39(5), 536-554. doi:10.1080/07399332.2018.1446958

Tamayo, L. I., Vidaurre, T., Navarro, J., Casavilca, S., Aramburu, J. I., Calderon, M. ... Fejerman, L. (2018). Breast cancer subtype and survival among Indigenous American women in Peru. PLoS One, 13(9), e0201287. doi:10.1371/journal.pone.0201287

Tonelli, M., Connor Gorber, S., Joffres, M., Dickinson, J., Singh, H., Lewin, G., ... Liu, Y. Y. (2011). Recommendations on screening for breast cancer in average-risk women aged 40-74 years. CMAJ, 183(17), 1991-2001. doi:10.1503/cmaj.110334

Vieira, R. A., Biller, G., Uemura, G., Ruiz, C. A. \& Curado, M. P. (2017). Breast cancer screening in developing countries. Clinics (Sao Paulo), 72(4), 244-253. doi:10.6061/clinics/2017(04)09

Wilkinson, R., \& Marmot, M. (2003). The social determinants of health. The Solid Facts. Geneva, $\mathrm{CH}$ : WHO.

Retrieved from:http://www.euro.who.int/_data/assets/pdf_file/0005/98438/e81384.pdf

World Health Organization (WHO) (2007). A Conceptual Framework for Action on the Social Determinants of Health: Discussion paper for the Commission on Social Determinants of Health. Geneva, Switzerland: $\quad$ WHO. from:http://www.who.int/social_determinants/resources/csdh_framework_action_05_07.pdf

World Health Organization (WHO) (2014). Position Paper on Mammography Screening. Geneva, Switzerland: WHO. Retrieved from:http://www.ncbi.nlm.nih.gov/books/NBK269545/

Zafra-Tanaka, J. H., Tenorio-Mucha, J., Villarreal-Zegarra, D., Carrillo-Larco, R. \& BernabeOrtiz A. (2020). Cancer-related mortality in Peru: Trends from 2003 to 2016. PLoS One, 15(2), e0228867. doi:10.1371/journal.pone.0228867

Zevallos, L., Pastor, R. \& Moscoso, B. (2011). Oferta y demanda de médicos especialistas en los establecimientos de salud del Ministerio de Salud: brechas a nivel nacional, por regiones y tipo de especialidad. Rev Peru Med Exp Salud Publica, 28(2), 177-85. doi:10.17843/rpmesp.2011.282.482 
Figure 1. Selection of participants, Peruvian women aged 50-to-59-year-old interviewed by the Demographic Health Survey, 2015.

33,543 men and women aged 15 to 59 surveyed in DHS 2015 Peru

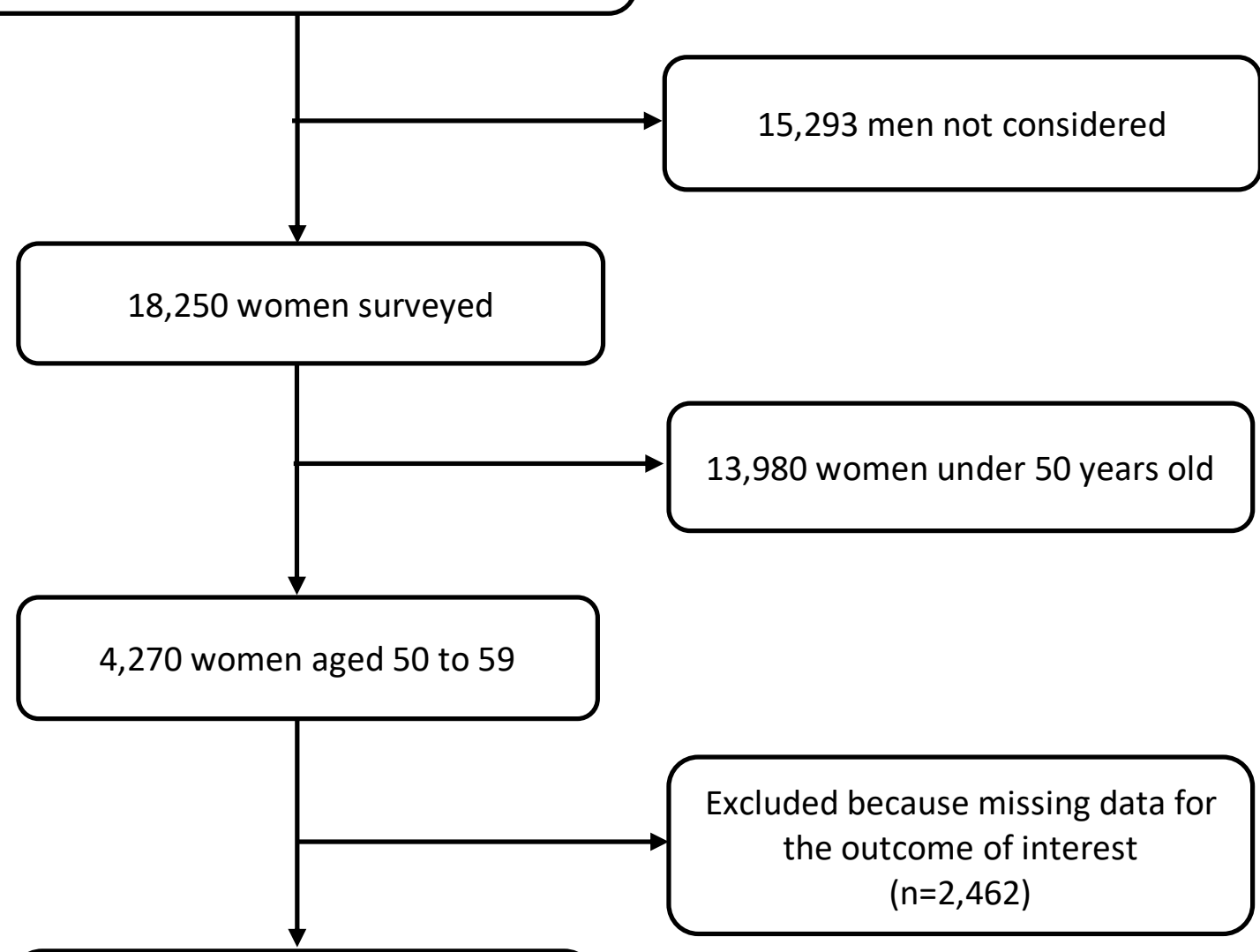

Participants included in the analysis $\mathrm{n}=1,808$ 
Figure 2. Prevalence of mammography screening within the past two years according to different social stratifiers among women aged 50 to 59 years, Peru 2015.

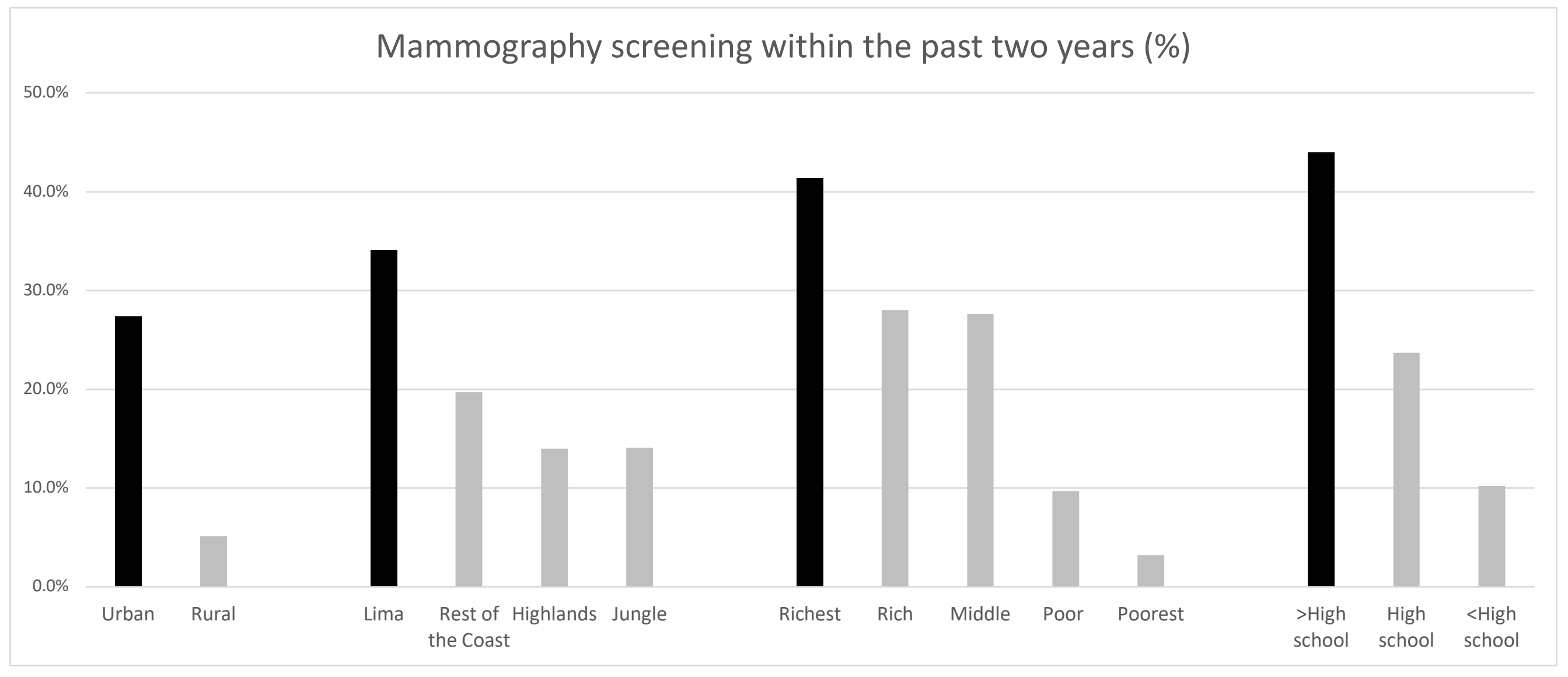


Table 1. Sociodemographic characteristics of women from 50-to-59-years-old, Peruvian Demographic Health Survey 2015. $(\mathrm{N}=1,808)$

\begin{tabular}{lcc}
\hline Characteristics & $\mathbf{n}^{\mathbf{a}}$ & $\mathbf{\%}$ \\
\hline Age, years (mean, s.d.) & 54.1 & 2.5 \\
Married/cohabiting & 1,185 & 64.9 \\
Area & & \\
Urban & 1,171 & 75.4 \\
Rural & 629 & 24.6 \\
Natural region & & \\
Lima & 206 & 31.4 \\
Rest of the coast & 552 & 26.8 \\
Highlands & 652 & 30.1 \\
Jungle & 398 & 11.7 \\
Socioeconomic status & & \\
Poorest & 491 & 19.5 \\
Poor & 427 & 21.3 \\
Middle & 331 & 17.0 \\
Rich & 322 & 22.2 \\
Richest & 237 & 20.0 \\
Education level & & \\
None/Primary school & 820 & 43.4 \\
High school & 478 & 29.5 \\
Higher education & 320 & 27.1 \\
Health Insurance & & \\
None & 407 & 25.2 \\
SIS-Ministry of Health & 930 & 44.0 \\
EsSalud & 420 & 26.9 \\
Police and Armed Forces & 34 & 2.3 \\
Private & 3 & 0.2 \\
More than one & 14 & 1.4 \\
Mammography screening $(<2$ years) & 329 & 21.9 \\
\hline & &
\end{tabular}

${ }^{a}$ Different total due to missing values.

All proportions consider the complex sampling design. 
Table 2. Social determinants associated with mammography screening within the past two years in women aged 50 to 59 years, Peru 2015: bivariate analysis.

\begin{tabular}{|c|c|c|c|c|c|}
\hline \multirow{3}{*}{ Characteristics } & \multicolumn{4}{|c|}{$\begin{array}{c}\text { Mammography screening within the past } 2 \\
\text { years }\end{array}$} & \multirow{3}{*}{$p^{\mathbf{b}}$} \\
\hline & \multicolumn{2}{|c|}{ No } & \multicolumn{2}{|c|}{ Yes } & \\
\hline & $n^{a}$ & $\%$ & $n^{a}$ & $\%$ & \\
\hline Age, years (mean, s.d.) & \multicolumn{2}{|c|}{$54.1 / 2.5$} & \multicolumn{2}{|c|}{$54.2 / 2.2$} & $0.781^{\mathrm{c}}$ \\
\hline Married/cohabiting & & & & & 0.652 \\
\hline No & 512 & 77.2 & 111 & 22.8 & \\
\hline Yes & 967 & 78.6 & 218 & 21.4 & \\
\hline Area & & & & & $<0.001$ \\
\hline Urban & 886 & 72.6 & 288 & 27.4 & \\
\hline Rural & 593 & 94.9 & 41 & 5.1 & \\
\hline Natural region & & & & & $<0.001$ \\
\hline Lima & 132 & 65.9 & 74 & 34.1 & \\
\hline Rest of the coast & 441 & 80.3 & 111 & 19.7 & \\
\hline Highlands & 566 & 86.0 & 86 & 14.0 & \\
\hline Jungle & 340 & 85.9 & 58 & 14.1 & \\
\hline Socioeconomic status & & & & & $<0.001$ \\
\hline Poorest & 472 & 96.8 & 19 & 3.2 & \\
\hline Poor & 382 & 90.3 & 45 & 9.7 & \\
\hline Middle & 260 & 72.4 & 71 & 27.6 & \\
\hline Rich & 226 & 72.0 & 96 & 28.0 & \\
\hline Richest & 139 & 58.6 & 98 & 41.4 & \\
\hline Education level & & & & & $<0.001$ \\
\hline$<$ High school & 747 & 89.8 & 73 & 10.2 & \\
\hline High school & 366 & 76.3 & 112 & 23.7 & \\
\hline$>$ High school & 184 & 56.0 & 136 & 44.0 & \\
\hline Health Insurance & & & & & $<0.001$ \\
\hline None & 372 & 92.6 & 35 & 7.4 & \\
\hline SIS-Ministry of Health & 842 & 87.4 & 88 & 12.6 & \\
\hline EsSalud & 236 & 54.4 & 184 & 45.6 & \\
\hline Others & 29 & 44.0 & 22 & 56.0 & \\
\hline
\end{tabular}

${ }^{a}$ Different total due to missing values.

${ }^{\mathrm{b}} \mathrm{chi}^{2}$

${ }^{\mathrm{c}}$ Mean difference

All proportions consider the complex sampling design. 
Table 3. Social determinants associated with mammography screening within the past two years in women aged 50 to 59 years, Peru 2015: crude and adjusted analysis.

\begin{tabular}{|c|c|c|c|c|c|c|}
\hline \multirow{2}{*}{ Social stratifiers ${ }^{a}$} & \multicolumn{2}{|c|}{ Crude model } & \multicolumn{2}{|c|}{ Model $1^{b}$} & \multicolumn{2}{|c|}{ Model $2^{\mathrm{c}}$} \\
\hline & PR & $95 \% \mathrm{CI}$ & $\overline{\text { aPR }}$ & $95 \% \mathrm{CI}$ & aPR & $95 \% \mathrm{CI}$ \\
\hline \multicolumn{7}{|l|}{ Area } \\
\hline Urban & 1 & Ref & 1 & Ref & 1 & Ref \\
\hline Rural & 0.18 & 0.12 to 0.27 & 0.18 & 0.12 to 0.27 & 0.97 & 0.54 to 1.76 \\
\hline \multicolumn{7}{|l|}{ Natural region } \\
\hline Lima & 1 & Ref & 1 & Ref & 1 & Ref \\
\hline Rest of the coast & 0.57 & 0.41 to 0.80 & 0.57 & 0.41 to 0.80 & 0.82 & 0.60 to 1.11 \\
\hline Mountain range & 0.41 & 0.28 to 0.58 & 0.41 & 0.28 to 0.59 & 0.80 & 0.56 to 1.12 \\
\hline Jungle & 0.41 & 0.27 to 0.61 & 0.41 & 0.27 to 0.61 & 0.80 & 0.54 to 1.20 \\
\hline \multicolumn{7}{|l|}{ Socioeconomic status } \\
\hline Poorest & 1 & Ref & 1 & Ref & 1 & Ref \\
\hline Poor & 3.04 & 1.59 to 5.80 & 3.02 & 1.59 to 5.76 & 2.57 & 1.14 to 5.80 \\
\hline Middle & 8.65 & 4.77 to 15.67 & 8.63 & 4.76 to 15.66 & 5.79 & 2.39 to 14.02 \\
\hline Rich & 8.79 & 4.89 to 15.80 & 8.76 & 4.88 to 15.74 & 4.63 & 1.85 to 11.60 \\
\hline Richest & 13.00 & 7.37 to 22.93 & 12.96 & 7.34 to 22.88 & 5.81 & 2.28 to 14.79 \\
\hline \multicolumn{7}{|l|}{ Education level } \\
\hline$<$ High school & 1 & Ref & 1 & Ref & 1 & Ref \\
\hline High school & 2.32 & 1.54 to 3.50 & 2.34 & 1.56 to 3.53 & 1.37 & 0.89 to 2.11 \\
\hline$>$ High school & 4.33 & 3.03 to 6.18 & 4.45 & 3.12 to 6.35 & 2.03 & 1.30 to 3.15 \\
\hline \multicolumn{7}{|l|}{ Health Insurance } \\
\hline None & 1 & Ref & 1 & Ref & 1 & Ref \\
\hline SIS-Ministry of Health & 1.71 & 1.00 to 2.93 & 1.72 & 1.00 to 2.94 & 2.23 & 1.29 to 3.85 \\
\hline EsSalud & 6.18 & 3.87 to 9.86 & 6.26 & 3.91 to 10.01 & 4.37 & 2.67 to 7.15 \\
\hline Others & 7.59 & 4.36 to 13.20 & 7.86 & 4.49 to 13.75 & 4.96 & 2.81 to 8.75 \\
\hline
\end{tabular}

${ }^{\mathrm{a}}$ All results consider the complex sampling design.

${ }^{\mathrm{b}}$ Model 1: Each social determinant, separately, adjusted by age and marriage/cohabitation status.

${ }^{\mathrm{c}}$ Model 2: Final model with all the social determinants included in the table, in addition to the variables age and marriage/cohabitation status.

PR: Prevalence ratio; aPR: adjusted prevalence ratio 